\title{
Biocatalytic synthesis of the Green Note trans-2-hexenal in a continuous-flow microreactor
}

\author{
Morten M. C. H. van Schie ${ }^{1}$, Tiago Pedroso de Almeida ${ }^{1}$, Gabriele Laudadio ${ }^{2}$, \\ Florian Tieves $^{1}$, Elena Fernández-Fueyo ${ }^{3}$, Timothy Noël ${ }^{*}{ }^{2}$ Isabel W. C. E. Arends ${ }^{1}$ \\ and Frank Hollmann ${ }^{* 1}$
}

\section{Letter}

\section{Address:}

${ }^{1}$ Department of Biotechnology, Delft University of Technology, Van der Maasweg 9, $2629 \mathrm{HZ}$ Delft, The Netherlands, ${ }^{2}$ Department of Chemical Engineering and Chemistry, Micro Flow Chemistry \& Process Technology, Eindhoven University of Technology, Den Dolech 2, 5612 AZ Eindhoven, The Netherlands and ${ }^{3}$ Centro de Investigaciones Biológicas, CSIC, Madrid, Spain

Email:

Timothy Noël* - t.noel@tue.nl; Frank Hollmann* -

f.hollmann@tudelft.nl

* Corresponding author

Keywords:

alcohol oxidase; alcohol oxidation; aldehyde; flow chemistry

\author{
Beilstein J. Org. Chem. 2018, 14, 697-703. \\ doi:10.3762/bjoc. 14.58 \\ Received: 20 October 2017 \\ Accepted: 15 March 2018 \\ Published: 26 March 2018 \\ This article is part of the Thematic Series "Integrated multistep flow \\ synthesis". \\ Guest Editor: V. Hessel \\ (C) 2018 van Schie et al.; licensee Beilstein-Institut. \\ License and terms: see end of document.
}

\begin{abstract}
The biocatalytic preparation of trans-hex-2-enal from trans-hex-2-enol using a novel aryl alcohol oxidase from Pleurotus eryngii ( $P e A A O x)$ is reported. As $\mathrm{O}_{2}$-dependent enzyme $P e A A O x$-dependent reactions are generally plagued by the poor solubility of $\mathrm{O}_{2}$ in aqueous media and mass transfer limitations resulting in poor reaction rates. These limitations were efficiently overcome by conducting the reaction in a flow-reactor setup reaching unpreceded catalytic activities for the enzyme in terms of turnover frequency (up to $38 \mathrm{~s}^{-1}$ ) and turnover numbers (more than 300000 ) pointing towards preparative usefulness of the proposed reaction scheme.
\end{abstract}

\section{Introduction}

trans-2-Hexenal is well-known as a major component of the Green Notes of fruits and vegetables such as apples, strawberries, cherries and more. It is widely used in the flavour and fragrance industry as fresh flavour ingredient in foods and beverages.

One attractive access to trans-2-hex-2-enal is the oxidation of the corresponding allylic alcohol to the aldehyde. Though at first sight an oxidation of primary alcohols to the corresponding aldehydes does not appear to be a major challenge, the methods of the state-of-the-art are mostly plagued by undesired side reactions [1]. Also some of the stoichiometric oxidants used are questionable from an environmental and/or toxicological point of view and therefore are not compatible with consumer products such as Green Notes. Therefore, we turned our attention to biocatalytic oxidation methods. For clean conver- 
sion of primary alcohols to aldehydes principally two biocatalytic approaches are available (Scheme 1) [2-5]. Alcohol dehydrogenases catalyse the reversible oxidation of alcohols in a Meerwein-Ponndorf-Verley-type of reaction (Scheme 1A). The poor thermodynamic driving force of this reaction, however, necessitates significant molar surpluses of the stoichiometric oxidant (such as acetone). This not only negatively influences the environmental impact of the reaction [6] but also complicates downstream processing. Furthermore, the nicotinamide cofactor (even if used in catalytic amounts only) causes additional costs.

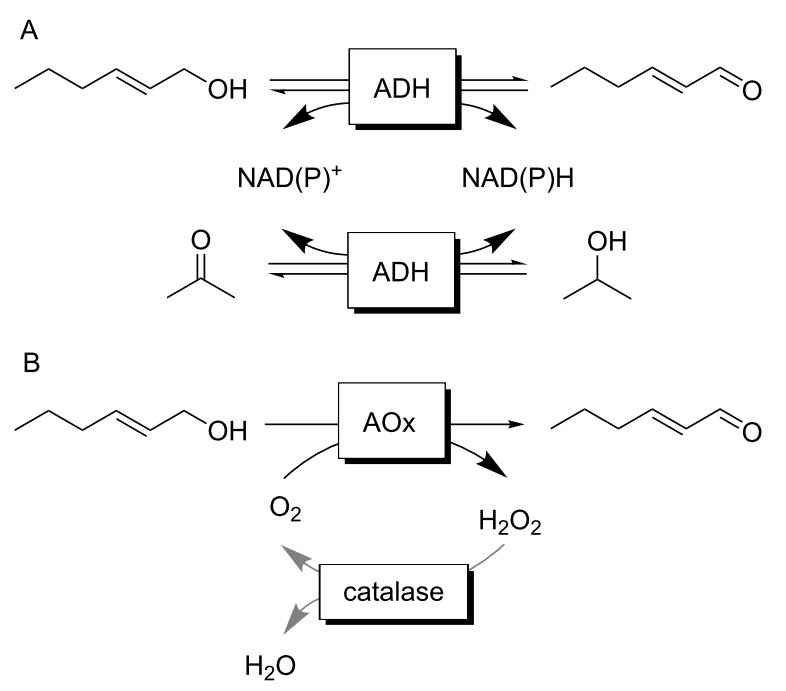

Scheme 1: Enzymatic reaction schemes for the selective oxidation of trans-hex-2-enol. A: Alcohol dehydrogenase (ADH)-catalysed oxidation producing stoichiometric amounts of $\mathrm{NAD}(\mathrm{P}) \mathrm{H}$, which needs to be recycled in situ; the overall reaction is reversible requiring surpluses of the cosubstrate (e.g., acetone) to shift the overall equilibrium to the side of trans-hex-2-enal. B: Envisioned aerobic oxidation using alcohol oxidases (AOx). $\mathrm{H}_{2} \mathrm{O}_{2}$ is formed as byproduct and dismutated by catalase into $\mathrm{H}_{2} \mathrm{O}$ and $\mathrm{O}_{2}$.

Therefore, we concentrated on alcohol oxidase-catalysed reaction schemes (Scheme 1B. Oxidases utilise $\mathrm{O}_{2}$ as terminal electron acceptor for the oxidation reaction yielding $\mathrm{H}_{2} \mathrm{O}_{2}$ as sole byproduct. The latter can be disproportionated easily by using catalase (Scheme 1B). Furthermore, $\mathrm{O}_{2}$ reduction adds sufficient thermodynamic driving force to the reaction to make it essentially irreversible.

The benefits of using $\mathrm{O}_{2}$, however, also come with the disadvantage of its very poor solubility in aqueous media (ca. $0.25 \mathrm{mM}$ at room temperature). Hence, in the course of an oxidation reaction dissolved $\mathrm{O}_{2}$ is consumed rapidly and diffusion of $\mathrm{O}_{2}$ into the reaction medium can easily become overall ratelimiting. The $\mathrm{O}_{2}$ diffusion rate into the reaction medium directly correlates with the interfacial area between aqueous medium and the gas phase. Large interfacial surface areas can be achieved via heterogeneous intake, by bubbling, stirring, etc. Soluble enzymes, however, are often rather unstable under these conditions, possibly owing to the mechanical stress leading to irreversible inactivation of the biocatalyst $[7,8]$. Methods of bubble-free aeration have been described in the literature to alleviate the inactivation issue described above [9-12].

The continuous-flow microreactor technology has emerged as a safe and scalable way to approach oxidation reactions $[13,14]$. Due to its small dimensions, hazardous reactions can be easily controlled, owing to the large surface-to-volume ratio which can minimise hot-spot formation and allows for control over mixing and heating phenomena $[15,16]$. Furthermore, a welldefined gas-liquid regime can be easily maintained $[17,18]$. High mass-transfer coefficients are generally the consequence of small vortices induced by the segmented flow regime. This flow pattern guarantees an enhanced contact between the two phases and provides a uniform gas concentration in the liquid segment.

Therefore, it is not very astonishing that also the biocatalysis community is showing interest in flow chemistry. Several biocatalytic processes have been reported in flow reactors [19], mostly advocating easier process intensification in combination with enzyme immobilization [20-23]. Also the higher oxygentransfer rates in flow reactions compared to batch reactions have been emphasised by several groups. Here, reactor designs ranging from simple flow reactors, tube-in-tube reactors [24], agitated tube reactors $[25,26]$ and continuous agitated cell reactors [27] have been reported.

Encouraged by these contributions, we asked ourselves whether a slug-flow approach may combine mechanically less demanding conditions with high $\mathrm{O}_{2}$-transfer rates thereby enabling efficient and robust oxidase-catalysed oxidation reactions.

\section{Results and Discussion Selection and characterisation of the biocatalyst}

As biocatalyst for this study we focussed on the recombinant aryl alcohol oxidase from Pleurotus eryngii (PeAAOx) [28-31]. Especially the availability as recombinant enzyme (enabling future at-scale production and protein engineering) and its promising activity on allylic alcohols make PeAAOx a promising starting point. Commercially available alcohol oxidases from Pichia pastoris and Candida boidinii showed no significant activity for the substrate under the same conditions. As trans-2-hex-enol had not been reported as substrate for 
PeAAOx we evaluated its catalytic properties, particularly the substrate concentration-dependency of the enzymatic oxidation. Initial rate measurements (performed in $1 \mathrm{~mL}$ cuvettes) revealed a Michaelis-Menten dependency of the enzyme activity (Figure 1). Apparent $K_{\mathrm{M}}$ and $k_{\text {cat }}$ values of approximately $1 \mathrm{mM}$ and $22 \mathrm{~s}^{-1}$ were estimated, respectively. These values are in the same order of magnitude as those for benzyl alcohol substrates reported previously [29]. The slightly decreasing enzyme activity at elevated substrate concentrations may be an indication for a slight substrate inhibition. Performing these initial rate measurements in the presence of varying product concentrations showed a pronounced product inhibition (Supporting Information File 1, Figure S2, vide infra).

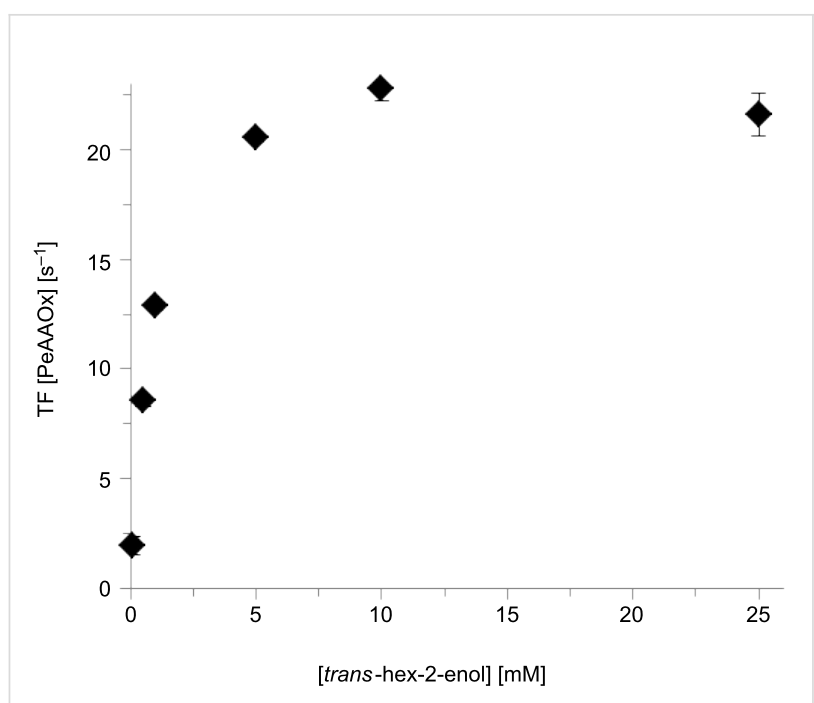

Figure 1: Michaelis-Menten kinetics of the PeAAOx-catalysed oxidation of trans-hex-2-enol. Conditions: $50 \mathrm{mM} \mathrm{KP}$ buffer $\left(\mathrm{pH} 7,30^{\circ} \mathrm{C}\right)$, $[\text { trans-hex-2-enol }]_{0}=3 \mathrm{mM},[\mathrm{PeAAOx}]=0.044 \mu \mathrm{M}$, [horseradish peroxidase $]=500 \mathrm{U} \mathrm{mL}^{-1},[$ ABTS $]=2 \mathrm{mM}$.

\section{Continuous-flow reactor enzymatic oxidation}

Next, we performed the PeAAOx-catalysed oxidation of transhex-2-enol in a slug-flow reactor setup (Supporting Information File 1, Figure S1 and Figures S9-S11). In a first set of experiments we systematically varied the residence time of the reaction mixture in the flow reactor (and thereby the reaction time, Figure 2).

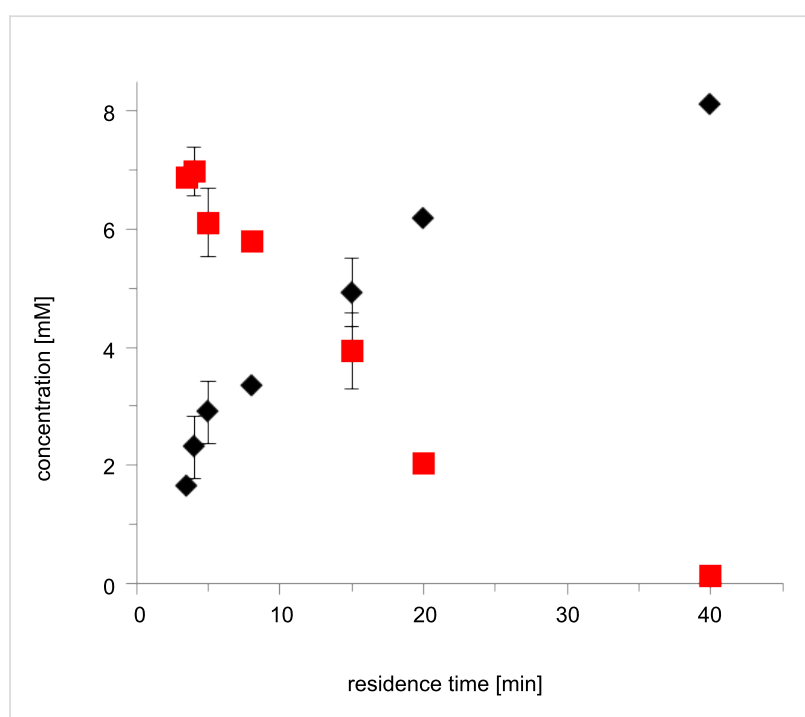

Figure 2: The influence of the residence time on the conversion of trans-hex-2-enol (red squares) to trans-2-hexenal (black diamonds) in a flow reactor. Conditions: $3 \mathrm{~mL}$ flow reactor, $50 \mathrm{mM} \mathrm{KP}$, buffer $(\mathrm{pH} 7$, $\left.30{ }^{\circ} \mathrm{C}\right)$, $[\text { trans-hex-2-enol }]_{0}=10 \mathrm{mM},[$ PeAAOx $]=0.25 \mu \mathrm{M},[$ catalase $]=$ $600 \mathrm{U} \mathrm{mL}^{-1}$.

A full conversion of the starting material into the desired transhex-2-enal was observed at residence (reaction) times of approximately $40 \mathrm{~min}$ corresponding to a turnover number (TN) for the biocatalysts of 32400 and an average turnover frequency (TF) of $13.5 \mathrm{~s}^{-1}$. Even more interestingly, at higher flow rates apparent $\mathrm{TF}$ of up to $38 \mathrm{~s}^{-1}(\mathrm{RT}=5 \mathrm{~min})$ were observed. This value exceeds the previously determined $k_{\text {cat }}(P e \mathrm{AAOx})$ (Figure 1) significantly. We attribute this observation to an increased oxygen-transfer rate at high flow rates. In the case of the 5 minutes residence time this corresponds to an $\mathrm{O}_{2}$-transfer

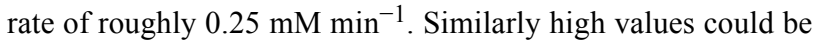
obtained previously only under mechanically demanding reaction conditions or using surfactant-stabilised emulsions [7]. Varying the ratio of gas to liquid had no significant effect on the overall rate of the reaction (Table 1).

Table 1: Effect of variation of the gas-to-liquid ratio on the rate of the PeAAOx-catalysed aerobic oxidation of trans-hex-2-enol.

\begin{tabular}{|c|c|c|c|c|}
\hline $\begin{array}{c}\text { ratio } \\
\text { (liquid:gas) }\end{array}$ & $\begin{array}{l}\text { liquid flow } \\
{\left[\mathrm{mL} \mathrm{min}^{-1}\right]}\end{array}$ & $\begin{array}{l}\text { gas flow } \\
{\left[\mathrm{mL} \mathrm{min}^{-1}\right]}\end{array}$ & residence time [min] & $\begin{array}{c}\text { [product] } \\
{[\mathrm{mM}]}\end{array}$ \\
\hline $1: 1$ & 0.20 & 0.20 & 15 & $5.48( \pm 0.01)$ \\
\hline $1: 3$ & 0.10 & 0.30 & 15 & $5.18( \pm 0.32)$ \\
\hline $1: 5$ & 0.067 & 0.333 & 16 & $4.99( \pm 0.49)$ \\
\hline
\end{tabular}

Conditions: $3 \mathrm{~mL}$ flow reactor, $50 \mathrm{mM} \mathrm{KP}$ buffer $\left(\mathrm{pH}\right.$, $\left.30^{\circ} \mathrm{C}\right)$, [trans-2-hexen-1-ol $]_{0}=10 \mathrm{mM},[P e A A O x]=0.25 \mu \mathrm{M},[\mathrm{catalase}]=600 \mathrm{U} \mathrm{mL}^{-1}$. 
Within the experimental error, the conversion in all experiments was identical indicating that even at a comparably low volumetric ratio of $1: 1$ the $\mathrm{O}_{2}$ availability was already sufficient not to be overall rate-limiting.

It is worth mentioning here that under batch reaction conditions, similar progression curves were only attainable under mechanically very demanding conditions (i.e., very vigorous stirring and bubbling of $\mathrm{O}_{2}$ directly into the reaction mixture, Supporting Information File 1, Figure S3). These conditions also caused a significant evaporation of the substrate at higher substrate concentration (Supporting Information File 1, Figure S4), which was much less the case in the flow-reaction setup.

From an economical point-of-view the catalyst performance in terms of turnover number (TN) is of utmost importance as it directly correlates with the cost-contribution of the catalyst to the production costs [32-34]. Therefore we evaluated the TN attainable for $P e A A O x$ in the flow setup (Figure 3). For this lower PeAAOx concentrations as well as significantly increased residence times were applied. The increased residence times were achieved by decreasing the flow rates and using a longer flow reactor (6 $\mathrm{mL}$ volume instead of $3 \mathrm{~mL}$ ).

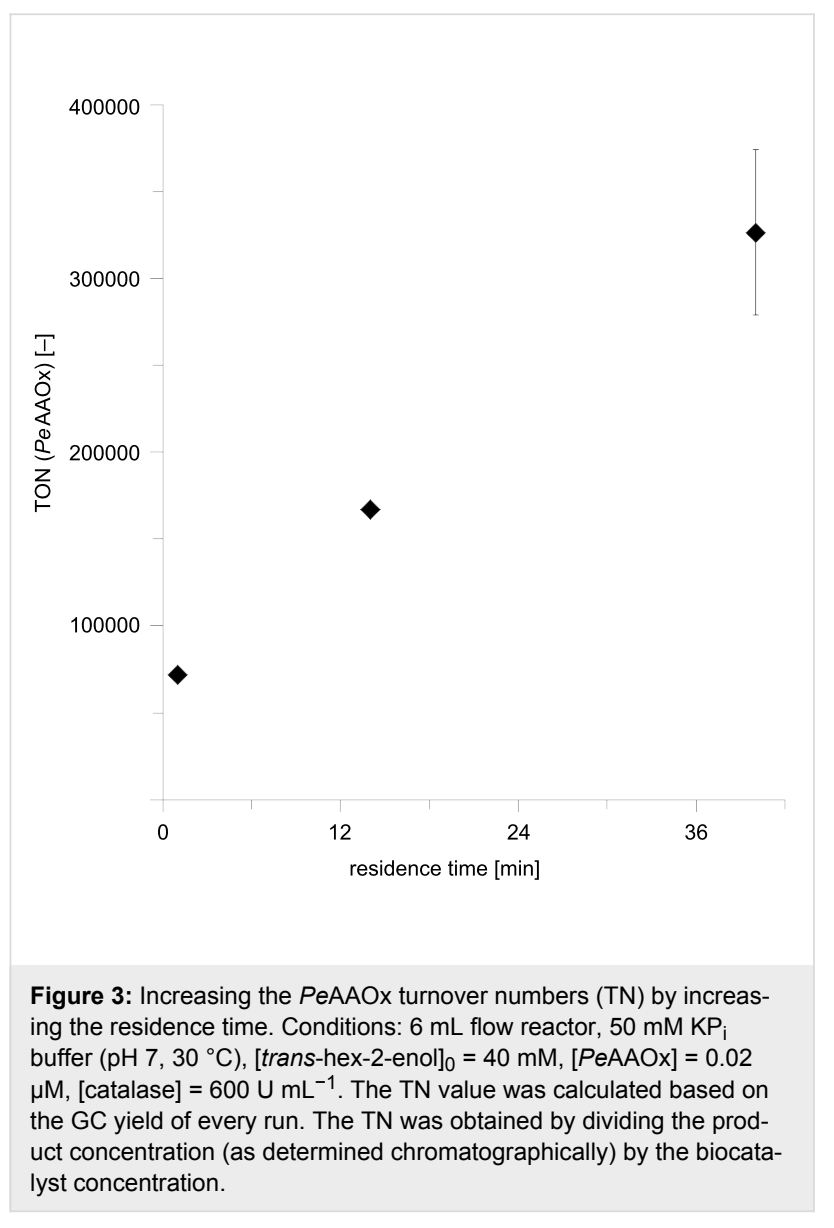

Pleasingly, already in these first experiments a TN for the enzyme of more than 300000 was observed at long residence times. This also underlines the robustness of the enzyme under the flow conditions. Compared to Figure 2 somewhat lower TFs for $P e A A O x$ were observed here, which again can be attributed to a lower $\mathrm{O}_{2}$-transfer rate at lower flow rates. The quasi-linear relationship shown in Figure 3 also suggests that even higher TN may be attainable - however at the expense of longer reaction times. Therefore, further investigations will focus on identifying conditions satisfying the demand for high TNs and short reaction times. Encouraged by these results, we also tried a semi-preparative scale reaction using $5 \mathrm{~g} \mathrm{~L}^{-1}(50 \mathrm{mM})$ substrate loading in a total of $50 \mathrm{~mL}$ with $0.75 \mu \mathrm{M}$ PeAAOx. As a result, $90 \%$ conversion was achieved after $18 \mathrm{~h}$ of total reaction time (roughly 80 minutes of residence time in the $6 \mathrm{~mL}$ reactor). The product was purified chromatographically resulting in 200 $\mathrm{mg}$ of pure trans-hex-2-enal (as determined by NMR) in $81 \%$ isolated yield thereby demonstrating the preparative potential of the proposed reaction setup.

\section{Conclusion}

Alcohol oxidase-catalysed oxidation of alcohols to aldehydes bears a significant potential for preparative biocatalysis. The reaction is independent from expensive and instable nicotinamide cofactors (and the corresponding cosubstrates/coproducts as well as possible regeneration enzymes) and produces only water as byproduct. These advantages, however, are counteracted by the generally low reaction rates caused by the poor $\mathrm{O}_{2}$ availability. Flow chemistry is a promising technique to provide the aqueous reaction mixture with $\mathrm{O}_{2}$ needed for the oxidation. It enables high $\mathrm{O}_{2}$ transfer rates while avoiding enzyme robustness issues frequently observed with 'traditional' aeration methods.

Future developments in our laboratories will concentrate on the characterisation, extension and preparative demonstration of this powerful combination of oxidase catalysis and flow chemistry.

\section{Experimental General}

Turnover numbers (TN) and turnover frequencies (TF) reported in this manuscript were calculated based on Equation 1 and Equation 2.

$$
\begin{gathered}
\mathrm{TN}[-]=\frac{c(\text { product })}{c(\text { PeAAOx })} \\
\mathrm{TF}\left[\mathrm{s}^{-1}\right]=\frac{\mathrm{TN}}{\text { reaction time }}
\end{gathered}
$$




\section{Production of PeAAOx}

\section{E. coli cultivation}

For the production, activation and purification of PeAAOx, a slightly modified literature protocol was used [28]. Pre-cultures of LB media containing $100 \mu \mathrm{g} \mathrm{mL}^{-1}$ of ampicillin were inoculated with $E$. coli $\mathrm{W} 3110$ containing pFLAG1-AAO and incubated overnight at $37{ }^{\circ} \mathrm{C}$ and $180 \mathrm{rpm}$. Overexpression was carried out in $5 \mathrm{~L}$ flasks with $1 \mathrm{~L}$ of TB medium supplemented with $100 \mu \mathrm{g} \mathrm{mL}^{-1}$ of ampicillin. The medium was inoculated with the pre-culture to an OD of 0.05 and grown at $37{ }^{\circ} \mathrm{C}$ and $180 \mathrm{rpm}$. At an $\mathrm{OD}_{600}$ of $0.8,1 \mathrm{mM}$ isopropyl $\beta$-D-thiogalactopyranoside (IPTG) was added and the cultures were incubated for additional $4 \mathrm{~h}$ at $37^{\circ} \mathrm{C}$ and $180 \mathrm{rpm}$. The bacterial pellets, obtained after harvesting the cells, were re-suspended in a total volume of $40 \mathrm{~mL} 50 \mathrm{mM} \mathrm{Tris} / \mathrm{HCl}$ buffer, $\mathrm{pH} 8.0$, containing $10 \mathrm{mM}$ EDTA and $5 \mathrm{mM}$ dithiothreitol (DTT).

\section{Refolding}

The re-suspended cells were disrupted by incubation with $2 \mathrm{mg} \mathrm{mL}{ }^{-1}$ lysozyme for $1 \mathrm{~h}$ at $4{ }^{\circ} \mathrm{C}$. Afterwards, $0.1 \mathrm{mg} \mathrm{mL}^{-1}$ DNase, $1 \mathrm{mM} \mathrm{MgCl} 2$ and $0.1 \mathrm{mM}$ PMSF were added followed by sonication. The insoluble fraction was collected by centrifugation $\left(30 \mathrm{~min}\right.$ at $15,000 \mathrm{rpm}$ and $4{ }^{\circ} \mathrm{C}$ ), re-suspended and washed three times with $20 \mathrm{~mL} 20 \mathrm{mM}$ Tris/ $\mathrm{HCl}$ buffer, $\mathrm{pH} 8.0$, containing $10 \mathrm{mM}$ EDTA and $5 \mathrm{mM}$ DTT using a potter homogenizing device. The pellets obtained after centrifugation (15 min at $15,000 \mathrm{rpm}$ and $4{ }^{\circ} \mathrm{C}$ ) were solubilized in a total volume of $30 \mathrm{~mL} 20 \mathrm{mM}$ Tris/ $\mathrm{HCl}$ buffer, $\mathrm{pH} 8.0$, containing $2 \mathrm{mM}$ EDTA, $50 \mathrm{mM}$ DTT and $8 \mathrm{M}$ urea. After incubation on ice for $30 \mathrm{~min}$, the solution was cleared by centrifugation (15 min at $15,000 \mathrm{rpm}$ and $4{ }^{\circ} \mathrm{C}$ ). The obtained supernatant was used as stock solution for the in vitro refolding.

The $P e$ AAOx was solubilized using $150 \mu \mathrm{g} \mathrm{mL}^{-1}$ protein in $20 \mathrm{mM}$ Tris/ $\mathrm{HCl}$ buffer, $\mathrm{pH} 9.0$, containing $2.5 \mathrm{mM} \mathrm{GSSG}$, $1 \mathrm{mM}$ DTT, $0.02 \mathrm{mM}$ FAD, 34\% glycerol and $0.6 \mathrm{M}$ urea at $4{ }^{\circ} \mathrm{C}$ for $80 \mathrm{~h}$. After the incubation for PeAAOx activation/ refolding, the refolding mixture was concentrated to $100 \mathrm{~mL}$ and the buffer exchanged against $10 \mathrm{mM}$ sodium phosphate buffer, pH 5.5 by diafiltration (DV 20) and subsequently concentrated using an Amicon Ultra $15 \mathrm{~mL}$ centrifugal filter (MWCO $10 \mathrm{kDa}$ ). After centrifugation (overnight at 15,000 rpm and $4{ }^{\circ} \mathrm{C}$ ), the soluble fraction was further purified using anionexchange chromatography.

\section{Purification}

The concentrated $P e A A O x$ solution was purified using a $58 \mathrm{~mL}$ Q Sepharose column (GE Healthcare). PeAAOx was eluted with a linear $\mathrm{NaCl}$ gradient $(0-0.6 \mathrm{M}$ over $6 \mathrm{CV})$ using $10 \mathrm{mM}$ sodium phosphate buffer, $\mathrm{pH}$ 5.5. Fractions containing
PeAAOx were pooled, concentrated and desalted using HiTrap desalting columns (GE Healthcare) and $10 \mathrm{mM}$ sodium phosphate buffer, $\mathrm{pH}$ 5.5. The PeAAOx concentration was calculated based on the absorbance using the molar extinction coefficient of $\varepsilon_{463} 11,050 \mathrm{M}^{-1} \mathrm{~cm}^{-1}$.

\section{Activity assay}

The activity of PeAAOx was determined by UV-vis spectroscopy, using an Agilent Cary $60 \mathrm{UV}$-vis spectrophotometer, following the oxidation of ABTS $\left(\varepsilon_{405}=36,800 \mathrm{M}^{-1} \mathrm{~cm}^{-1}\right)$ by horseradish peroxidase (POD) at the expense of hydrogen peroxide. In general, $0.044 \mu \mathrm{M} P e A A O x$ was used to convert $3 \mathrm{mM}$ of trans-2-hex-2-enol. The hydrogen peroxide formed in this reaction was subsequently used to convert $2 \mathrm{mM}$ of ABTS to $\mathrm{ABTS}^{-+}$by an excess of POD $\left(500 \mathrm{U} \mathrm{mL}^{-1}\right)$. The reactions were performed at $30{ }^{\circ} \mathrm{C}$ in oxygen-saturated $50 \mathrm{mM} \mathrm{KP_{i }}$ buffer at $\mathrm{pH}$ 7.0.

\section{Flow reactor experiments}

PFA microreactor coils (750 $\mu \mathrm{m}$ ID) with a volume of 3 and $6 \mathrm{~mL}$ were constructed. The reaction mixture was introduced via a syringe pump (Fusion 200, Chemyx), while the pure oxygen flow was controlled by a mass flow controller (ELFLOW, Bronkhorst), resulting in a segmented flow (Supporting Information File 1, Figure S8). Residence times were taken as the time between the solution entering and exiting the coil and were varied by altering the flow, keeping the ratio of oxygen to liquid at three to one. Samples were collected on ice and as soon as enough volume was collected, extracted with ethyl acetate and analysed by GC (vide infra).

\section{GC analysis}

The collected reaction mixtures were extracted into an equal volume of ethyl acetate, dried with magnesium sulphate and analysed on a CP-wax $52 \mathrm{CB}$ GC column $(50 \mathrm{~m} \times 0.53 \mathrm{~m} \times$ $2 \mu \mathrm{m}$ ) (GC method: $60{ }^{\circ} \mathrm{C}$ for $3 \mathrm{~min} ; 30^{\circ} \mathrm{C} / \mathrm{min}$ to $105^{\circ} \mathrm{C}$; $105^{\circ} \mathrm{C}$ for $7 \mathrm{~min} ; 30^{\circ} \mathrm{C} / \mathrm{min}$ to $250{ }^{\circ} \mathrm{C}$; $250{ }^{\circ} \mathrm{C}$ for 1 minute). Dodecane $(5 \mathrm{mM})$ was added as standard.

\section{Work-up semi-preparative scale}

The reaction mixture was directly collected in deuterated chloroform at the end of the flow reactor followed by recording the NMR spectrum in order to evaluate the conversion (see Supporting Information File 1). The organic mixture was diluted and introduced into a separation funnel and washed with brine. The aqueous phase was backwashed once with DCM. The collected organic phase was dried over $\mathrm{MgSO}_{4}$, filtered and concentrated under reduced pressure. Purification of the isolated mixture was performed by flash chromatography on silica (pure DCM). The final product was obtained as colourless oil (200 mg). 
(E)-Hex-2-enal

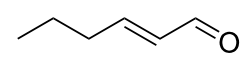

TLC (DCM) $R_{\mathrm{f}} 0.9 ;{ }^{1} \mathrm{H}$ NMR $\left(399 \mathrm{MHz}, \mathrm{CDCl}_{3}\right) \delta 9.44(\mathrm{~d}, J=$ $7.7 \mathrm{~Hz}, 1 \mathrm{H}), 6.78$ (dt, $J=15.6,6.8 \mathrm{~Hz}, 1 \mathrm{H}), 6.05$ (ddq, $J=15.5$, 7.8, $1.3 \mathrm{~Hz}, 1 \mathrm{H}), 2.33-2.18$ (m, 2H), 1.48 (h, $J=7.4 \mathrm{~Hz}, 2 \mathrm{H})$, $0.90(\mathrm{t}, J=7.4 \mathrm{~Hz}, 3 \mathrm{H}) ;{ }^{13} \mathrm{C} \mathrm{NMR}\left(101 \mathrm{MHz}, \mathrm{CDCl}_{3}\right) \delta 194.3$, $158.9,133.3,34.8,21.3,13.8$.

\section{Supporting Information}

\section{Supporting Information File 1}

General information and supporting figures.

[https://www.beilstein-journals.org/bjoc/content/

supplementary/1860-5397-14-58-S1.pdf]

\section{Acknowledgements}

We thank the Netherlands Organisation for Scientific Research for financial support through a VICI grant (no. 724.014.003).

\section{ORCID ${ }^{\circledR}$ iDs}

Gabriele Laudadio - https://orcid.org/0000-0002-2749-8393

Timothy Noël - https://orcid.org/0000-0002-3107-6927

Frank Hollmann - https://orcid.org/0000-0003-4821-756X

\section{References}

1. Alshammari, H.; Miedziak, P. J.; Morgan, D. J.; Knight, D. W.; Hutchings, G. J. Green Chem. 2013, 15, 1244-1254. doi:10.1039/C3GC36828A

2. Turner, N. J. Chem. Rev. 2011, 111, 4073-4087. doi:10.1021/cr200111v

3. Hollmann, F.; Arends, I. W. C. E.; Buehler, K.; Schallmey, A.; Bühler, B. Green Chem. 2011, 13, 226-265. doi:10.1039/c0gc00595a

4. Kroutil, W.; Mang, H.; Edegger, K.; Faber, K. Curr. Opin. Chem. Biol. 2004, 8, 120-126. doi:10.1016/j.cbpa.2004.02.005

5. Pickl, M.; Fuchs, M.; Glueck, S. M.; Faber, K. Appl. Microbiol. Biotechnol. 2015, 99, 6617-6642. doi:10.1007/s00253-015-6699-6

6. Ni, Y.; Holtmann, D.; Hollmann, F. ChemCatChem 2014, 6, 930-943. doi:10.1002/cctc.201300976

7. Churakova, E.; Arends, I. W. C. E.; Hollmann, F. ChemCatChem 2013, 5, 565-568. doi:10.1002/cctc.201200490

8. Bommarius, A. S.; Karau, A. Biotechnol. Prog. 2005, 21, 1663-1672. doi:10.1021/bp050249q

9. Van Hecke, W.; Ludwig, R.; Dewulf, J.; Auly, M.; Messiaen, T.; Haltrich, D.; Van Langenhove, H. Biotechnol. Bioeng. 2009, 102, 122-131. doi:10.1002/bit.22042

10. Van Hecke, W.; Bhagwat, A.; Ludwig, R.; Dewulf, J.; Haltrich, D.; Van Langenhove, H. Biotechnol. Bioeng. 2009, 102, 1475-1482. doi:10.1002/bit.22165

11. Illner, S.; Hofmann, C.; Löb, P.; Kragl, U. ChemCatChem 2014, 6, 1748-1754. doi:10.1002/cctc.201400028
12. Kaufhold, D.; Kopf, F.; Wolff, C.; Beutel, S.; Hilterhaus, L.; Hoffmann, M.; Scheper, T.; Schlüter, M.; Liese, A. J. Membr. Sci. 2012, 423-424, 342-347. doi:10.1016/j.memsci.2012.08.035

13. Gemoets, H. P. L.; Su, Y.; Shang, M.; Hessel, V.; Luque, R.; Noël, T. Chem. Soc. Rev. 2016, 45, 83-117. doi:10.1039/C5CS00447K

14. Plutschack, M. B.; Pieber, B.; Gilmore, K.; Seeberger, P. H. Chem. Rev. 2017, 117, 11796-11893. doi:10.1021/acs.chemrev.7b00183

15. Kockmann, N.; Thenée, P.; Fleischer-Trebes, C.; Laudadio, G.; Noël, T. React. Chem. Eng. 2017, 2, 258-280. doi:10.1039/C7RE00021A

16. Gutmann, B.; Cantillo, V.; Kappe, C. O. Angew. Chem., Int. Ed. 2015, 54, 6688-6728. doi:10.1002/anie.201409318

17. Noël, T.; Su, Y.; Hessel, V. Beyond Organometallic Flow Chemistry: The Principles Behind the Use of Continuous-Flow Reactors for Synthesis. Organometallic Flow Chemistry; Topics in Organometallic Chemistry, Vol. 57; Springer, 2016; pp 1-41. doi:10.1007/3418_2015_152

18. Mallia, C. J.; Baxendale, I. R. Org. Process Res. Dev. 2016, 20 , 327-360. doi:10.1021/acs.oprd.5b00222

19. Tamborini, L.; Fernandes, P.; Paradisi, F.; Molinari, F. Trends Biotechnol. 2018, 36, 73-88. doi:10.1016/j.tibtech.2017.09.005

20. Peris, E.; Okafor, O.; Kulcinskaja, E.; Goodridge, R.; Luis, S. V.; Garcia-Verdugo, E.; O'Reilly, E.; Sans, V. Green Chem. 2017, 19, 5345-5349. doi:10.1039/C7GC02421E

21. Bolivar, J. M.; Wiesbauer, J.; Nidetzky, B. Trends Biotechnol. 2011, 29, 333-342. doi:10.1016/j.tibtech.2011.03.005

22. Zor, C.; Reeve, H. A.; Quinson, J.; Thompson, L. A.; Lonsdale, T. H.; Dillon, F.; Grobert, N.; Vincent, K. A. Chem. Commun. 2017, 53, 9839-9841. doi:10.1039/C7CC04465H

23. Tang, X.; Allemann, R. K.; Wirth, T. Eur. J. Org. Chem. 2017, 414-418. doi:10.1002/ejoc.201601388

24. Tomaszewski, B.; Lloyd, R. C.; Warr, A. J.; Buehler, K.; Schmid, A. ChemCatChem 2014, 6, 2567-2576. doi:10.1002/cctc.201402354

25. Jones, E.; McClean, K.; Housden, S.; Gasparini, G.; Archer, I. Chem. Eng. Res. Des. 2012, 90, 726-731. doi:10.1016/j.cherd.2012.01.018

26. Gasparini, G.; Archer, I.; Jones, E.; Ashe, R. Org. Process Res. Dev. 2012, 16, 1013-1016. doi:10.1021/op2003612

27. Toftgaard Pedersen, A.; de Carvalho, T. M.; Sutherland, E.; Rehn, G.; Ashe, R.; Woodley, J. M. Biotechnol. Bioeng. 2017, 114, 1222-1230. doi:10.1002/bit.26267

28. Ruiz-Dueñas, F. J.; Ferreira, P.; Martinez, M. J.; Martinez, A. T. Protein Expression Purif. 2006, 45, 191-199. doi:10.1016/j.pep.2005.06.003

29. Ferreira, P.; Medina, M.; Guillén, F.; Martínez, M. J.; Van Berkel, W. J. H.; Martínez, A. T. Biochem. J. 2005, 389, 731-738. doi:10.1042/bj20041903

30. Guillén, F.; Martinez, A. T.; Martinez, M. J. Eur. J. Biochem. 1992, 209, 603-611. doi:10.1111/j.1432-1033.1992.tb17326.x

31. Guillén, F.; Martinez, A. T.; Martínez, M. J. Appl. Microbiol. Biotechnol. 1990, 32, 465-469. doi:10.1007/bf00903784

32. Bormann, S.; Gomez Baraibar, A.; Ni, Y.; Holtmann, D.; Hollmann, F. Catal. Sci. Technol. 2015, 5, 2038-2052. doi:10.1039/C4CY01477D

33. Toftgaard Pedersen, A.; Birmingham, W. R.; Rehn, G.; Charnock, S. J.; Turner, N. J.; Woodley, J. M. Org. Process Res. Dev. 2015, 19 , 1580-1589. doi:10.1021/acs.oprd.5b00278

34. Tufvesson, P.; Lima-Ramos, J.; Nordblad, M.; Woodley, J. M. Org. Process Res. Dev. 2011, 15, 266-274. doi:10.1021/op1002165 


\section{License and Terms}

This is an Open Access article under the terms of the Creative Commons Attribution License

(http://creativecommons.org/licenses/by/4.0), which permits unrestricted use, distribution, and reproduction in any medium, provided the original work is properly cited.

The license is subject to the Beilstein Journal of Organic Chemistry terms and conditions:

(https://www.beilstein-journals.org/bjoc)

The definitive version of this article is the electronic one which can be found at:

doi:10.3762/bjoc. 14.58 